\title{
Pengaruh Ciri Tekstur Pada Metode Klasifikasi LVQ Untuk Hasil Akurasi Identifikasi Citra Batik Tradisional Solo
}

\author{
Noor Abdul Haris ${ }^{1 *}$, Kusrini' ${ }^{2}$, Hanif Al Fatta ${ }^{3}$ \\ ${ }^{1,2,3}$ Program Studi S2-Magister Teknik Informatika, Universitas Amikom Yogyakarta \\ 1,2,3 Jln. Ring Road Utara, Condong Catur, Sleman Yogyakarta, Indonesia \\ E-mail: noor.haris@ students.amikom.ac.id $^{1}$, kusrini@ amikom.ac.id $^{2}$, hanif.a@ amikom.ac.id $^{3}$
}

\section{Info Naskah:}

Naskah masuk: 14 Juni 2020

Direvisi: 4 Agustus 2020

Diterima: 5 Agustus 2020

\begin{abstract}
Abstrak
Penggunaan ciri yang tepat untuk menentukan identifikasi sangat penting untuk hasil akurasi, khususnya citra batik tradisional Solo. Ciri disebut baik jika memiliki kemampuan pembeda sehingga dapat digunakan untuk pengenalan dengan tingkat akurasi yang tinggi. Tujuan dari penelitian ini untuk mengetahui ciri apa saja dari ciri tekstur yang berpengaruh pada tingkat akurasi pada identifikasi citra batik tradisional Solo. Metode yang digunakan KFold cross validation, dengan nilai K sebesar 2, 3, 5, 6, 10 digunakan untuk menguji data latih dan data validasi. Parameter terbaik dipilih dari nilai akurasi tertinggi, dan selanjutnya disimpan bobot akhir, nilai $\alpha, \operatorname{dec} \alpha \operatorname{dan} \min \alpha$ terbaik. Nilai-nilai yang dihasilkan yang digunakan dalam pengujian data uji. Ciri tekstur yang diuji adalah energi $0^{\circ}$, energi $45^{\circ}$, energi $90^{\circ}$, energi $135^{\circ}$, entropi $0^{\circ}$, entropi $45^{\circ}$, entropi $90^{\circ}$, entropi $135^{\circ}$, kontras $0^{\circ}$, kontras $45^{\circ}$, kontras $90^{\circ}$, kontras $135^{\circ}$, homogeniti $0^{\circ}$, homogeniti $45^{\circ}$, homogeniti $90^{\circ}$, homogeniti $135^{\circ}$, korelasi $0^{\circ}$, korelasi $45^{\circ}$, korelasi $90^{\circ}$, korelasi $135^{\circ}$. Hasil pengujian diperoleh dari $\mathrm{K}=2,3,5,6,10$ nilai akurasi tertinggi diperoleh pada 10 -fold dengan hasil akurasi sebesar 80,2\%. Hasil pengujian menggunakan k-fold dapat diambil kesimpulan penggunaan ciri tekstur dapat berpengaruh meningkatkan hasil akurasi sebesar $18,89 \%$.
\end{abstract}

\section{Keywords:}

K-Fold;

Batik;

Texture;

$L V Q$.

\section{Abstract}

The use of appropriate features to determine identification is very important for the results of accuracy, especially the image of traditional batik in Solo. Characteristics are considered as good if they have distinguishing abilities, so they can be used for recognition with a high degree of accuracy. The purpose of this study was to determine what texture characteristics affect the level of accuracy in the identification of traditional batik in Solo. The method used is KFold cross-validation, with a $\mathrm{K}$ value of 2, 3, 5, 6, 10 used to test the training data and validation data. The best parameters are chosen from the highest accuracy value, and then the best final weight, value $\alpha$, dec $\alpha$, and $\min \alpha$ are stored. The resulting values are used in testing the data. The texture characteristics tested were $0^{\circ}$ energy, $45^{\circ}$ energy, $90^{\circ}$ energy, $135^{\circ}$ energy, $0^{\circ}$ entropy, $45^{\circ}$ entropy, $90^{\circ}$ entropy, $135^{\circ}$ entropy, $0^{\circ}$ contrast, $45^{\circ}$ contrast, $90^{\circ}$ contrast, $135^{\circ}$ energy, $0^{\circ}$ homogeneity, $45^{\circ}$ homogeneity, $90^{\circ}$ homogeneity. , homogeneity $135^{\circ}$, correlation $0{ }^{\circ}$, correlation $45^{\circ}$, correlation $90^{\circ}$, correlation $135^{\circ}$. The test results obtained from $\mathrm{K}=2,3$, $5,6,10$ is the highest accuracy value obtained at 10 -fold with an accuracy of $80.2 \%$. The results of testing using $\mathrm{k}$-fold can be concluded that the use of texture characteristics can affect the accuracy of $18.89 \%$.

\section{*Penulis korespondensi:}




\section{Pendahuluan}

Batik tradisional memiliki karakteristik yang terdiri dari banyak ciri. Demikian juga dengan Batik tradisional Surakarta. Ciri yang digunakan untuk menjadi pembeda dengan ciri batik dari wilayah lain antara lain ciri bentuk[1][2][3][4][5], ciri tekstur [6][7][8][9][10], dan juga ciri warna [11][12]. Dari berbagai ciri yang digunakan untuk identifikasi batik daerah satu dengan yang lain ada yang memiliki kesamaan namun ada juga yang memiliki perbedaan. Masing-masing daerah memiliki corak dan ciri yang berbeda seperti batik Bali [13], batik Pekalongan [14], batik Banyuwangi [15], batik Surakarta [3] dan masih banyak lagi. Ciri yang digunakan untuk identifikasi Batik pada satu daerah belum tentu sama dengan daerah lain.[16][15][17][18] Untuk ciri tekstur memiliki banyak item yang dapat digunakan untuk dijadikan sebagai pembeda antara satu corak dengan corak yang lain, khususnya batik tradisional Surakarta yang memiliki 7 macam jenis corak yang satu dengan yang lain memiliki ciri khas [19][20][21].

Untuk itu menjadi penting dilakukan penelitian untuk memilih ciri yang terbaik dari banyak ciri yang digunakan, dimulai dari pemilihan ciri terbaik dari ciri tekstur dengan tujuan untuk mendapatkan akurasi yang terbaik. KFold cross validation merupakan metode yang dapat digunakan untuk nilai akurasi validasi tertinggi pada fold tersebut untuk mendapatkan bobot akhir, yang digunakan untuk menguji data baru [22][23][24]. Hasil ciri tekstur terbaik dari validasi digunakan selanjutnya untuk pengujian selanjutnya.

\section{Tinjauan Studi}

\subsection{K-Fold Cross Validation}

Metode statistik yang digunakan untuk mengevaluasi dan membandingkan algoritma pembelajaran yaitu $K$-fold Cross Validation. Cara kerja metode ini adalah membagi data menjadi dua yaitu untuk pelatihan dan pengujian. Data dibagi dengan ukuran yang sama, masing-masing data latih dan data validasi akan berfungsi menjadi data latih sebanyak sekali dan data pelatihan sebanyak (k-1) kali. Pada umumnya dalam data mining dan pembelajaran mesin menggunakan 10 fold cross validation [25]. Kelebihan metode ini adalah tidak adanya masalah dalam pembagian data. Kekurangan metode ini adalah pembelajaran harus dilakukan sebanyak $k$ kali yang berarti menggunakan $k$ kali waktu komputasi. Gambar 2 menunjukkan contoh $k$-fold cross validation dengan $\mathrm{K}=3$.

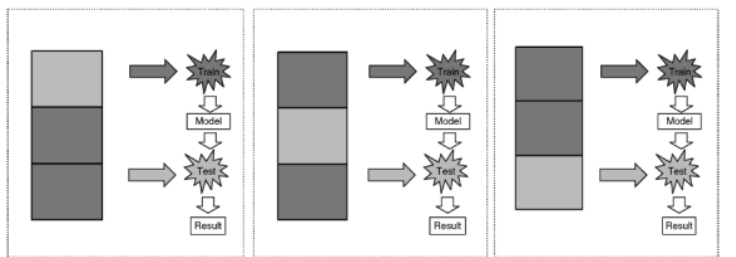

Gambar 2. Contoh K-Fold Cross Validation dengan K=3[25]

\subsection{Ekstraksi Fitur Tekstur dengan GLCM (Gray Level Co-Occurrence Matrix)}

Ekstraksi fitur yang digunakan dalam penelitian ini adalah GLCM. Nilai diperoleh dari perhitungan probabilitas ketetanggaan yang saling berhubungan antara dua pixel yang berada pada sudut dan jarak tertentu. Sebagai parameter terpenting pada GLCM ada tiga yaitu jarak, gray level dan sudut [22]. Jarak spasial 1 digunakan dengan pertimbangan komputasi yang lebih sederhana. Empat buah sudut yaitu $0^{\circ}, 45^{\circ}, 90^{\circ}, 135^{\circ}$, digunakan untuk mengetahui pengaruh sudut terhadap perubahan nilai fitur. Pada Gambar 1 menunjukkan tahapan-tahapan pada ekstraksi fitur menggunakan GLCM.

Fitur tekstur yang digunakan dalam penelitian ini energi, entropi, kontras, homogeniti, dan korelasi. Perhitungan fitur tekstur untuk satu data citra adalah diantaranya:

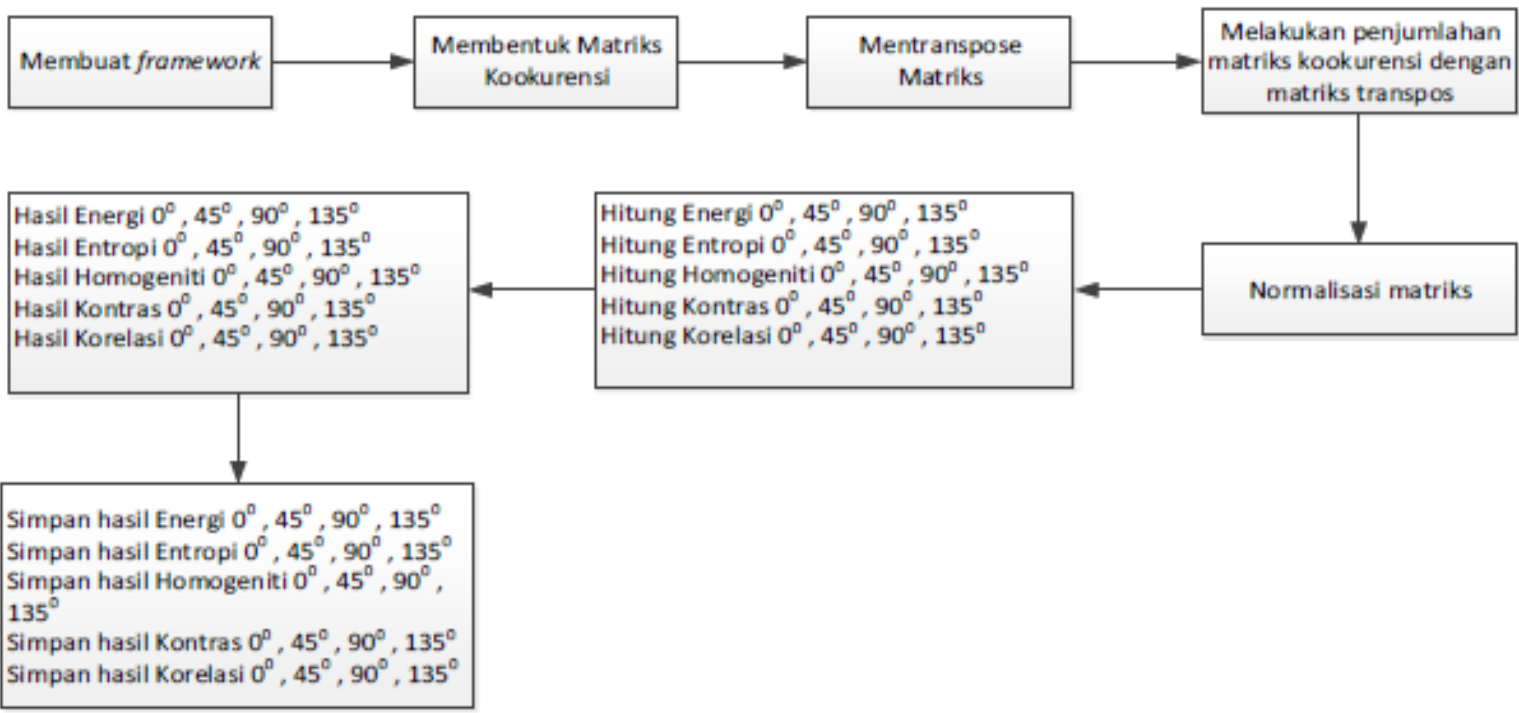

Gambar 1. Ekstraksi fitur tekstur dengan GLCM 
a. Energi (Energy)

$$
\sum_{i=1}^{K} \sum_{j=1}^{K} p_{i^{2} j}
$$

b. Entropi (Entropy)

$$
\sum_{i=1}^{K} \sum_{j=1}^{K} p_{i j} \log _{2} p_{i j}
$$

c. Kontras (Contrast)

$$
\sum_{i=1}^{K} \sum_{j=1}^{K}(i-j)^{2} p_{i j}
$$

d. Homogeniti (Homogeneity)

$$
\sum_{i=1}^{K} \sum_{j=1}^{K} \frac{p_{i j}}{1+|i-j|}
$$

e. Korelasi (Correlation)

$$
\sum_{i=1}^{K} \sum_{j=1}^{K} \frac{\left(i-m_{r}\right)\left(j-m_{c}\right) p_{i j}}{\sigma_{r} \sigma_{c}}
$$

$\mathrm{P}(\mathrm{i}, \mathrm{j})=$ matriks kookurensi dengan baris ke-i, kolom ke-j yang dinormalisasi. $m_{r}=$ rata-rata baris. $m_{c}=$ rata-rata kolom. $\sigma r$ dan $\sigma c=$ standar deviasi yang cara penghitungannya berdasarkan baris dan kolom secara berurutan. Ekstraksi fitur yang dihasilkan energi0 ${ }^{\circ}$, energi $45^{\circ}$, energi $90^{\circ}$, energi $135^{\circ}$, entropi $0^{\circ}$, entropi $45^{\circ}$,

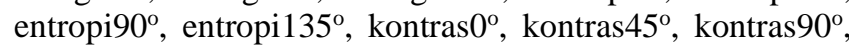
kontras $135^{\circ}$, homogeniti $0^{\circ}$, homogeniti $45^{\circ}$, homogeniti $90^{\circ}$, homogeniti $135^{\circ}$, korelasi0 $^{\circ}$, korelasi45 $^{\circ}, \quad$ korelasi $90^{\circ}$, korelasi135 ${ }^{\circ}$. Tahapan algoritma ekstraksi fitur tekstur GLCM sebagai berikut:

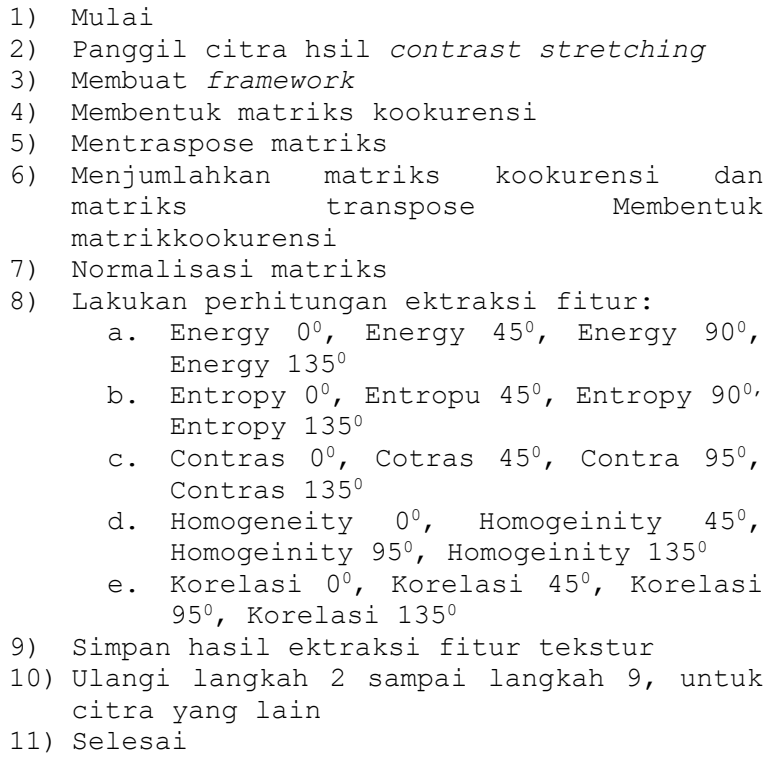

\subsection{Model Seleksi Fitur}

Penelitian ini terdapat 20 fitur dan 7 kelas untuk indentifikasi batik tradisional Surakarta. Diawali dengan melakukan pemanggilan data fitur tekstur dan dilanjutkan dengan menghitung fitur pertama yang dapat mengidentifikasi dengan benar dibagi dengan daata keseluruhan pada kelas pertama. Begitu selanjutnya untuk fitur kedua pada kelas pertama. Selanjutnya akan dibandingkan antara fitur pertama dan kedua sehingga mendapatkan fitur yang dominan. Selanjutnya akan dilakukan hal yang sama sampai dengan fitur keduapuluh. Pencarian berakhir saat penambahan fitur baru selanjutnya terjadi penurunan.

\subsection{Model LVQ (Learning Vector Quantization)}

Learning Vector Quantization (LVQ) merupakan metode untuk identifikasi jenis batik tradisional Surakarta, di mana setiap unit output mewakili kelas atau kategori tertentu. LVQ dalam penelitian ini, $\mathrm{X}_{1} \ldots \mathrm{X}_{20}$ merupakan fitur ke 1 sampai dengan fitur ke 20. $\mathrm{W}_{11} \ldots \mathrm{W}_{20} 7$ merupakan bobot yang menghubungkan input dengan output, bobot ke 1 untuk kelas 1 sampai dengan bobot ke 20 untuk kelas $7 . \mathrm{Y}_{1} \ldots \mathrm{Y}_{7}$ merupakan kelas 1 sampai dengan kelas 7. Pada Gambar 3 menunjukkan arsitektur jaringan LVQ.

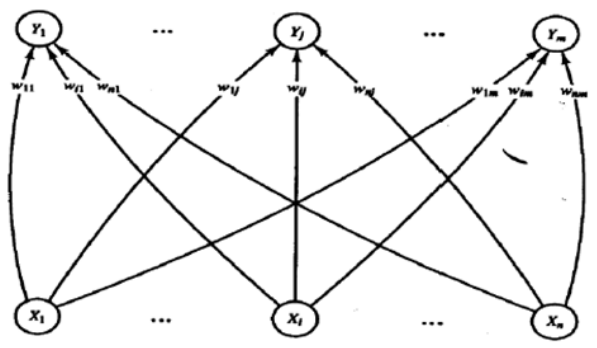

Gambar 3. Jaringan LVQ

Jika dua vektor input mendekati sama, maka lapisan kompetitif akan meletakkan kedua vektor input tersebut ke dalam kelas yang sama. Setelah pembelajaran, lapisan LVQ membagi vektor input dengan penempatan lapisan LVQ ke kelas yang sama sebagai unit ouput yang mempunyai vektor bobot (vektor referensi) terdekat dengan vektor input [22]

Pada proses pelatihan dan pengujian, LVQ mengunakan operasi-operasi vektor. LVQ ini mempunyai vektor bobot disetiap unit output yang sering disebut dengan codebook. Vektor bobot berfungsi untuk menghubungkan setiap neuron pada lapisan input dengan masing-masing neuron pada lapisan output. Selama proses pelatihan, LVQ melakukan update pada setiap vektor bobot dari unit yang mewakili tiap kelas. Setelah proses pelatihan selesai, dilakukan proses pengujian dengan pemanggilan bobot akhir dan data yang akan diuji [22] bobot merupakan parameter yang penting, karena dengan bobot ini input dapat melakukan pembelajaran dalam mengenali suatu pola.

\section{Metode Penelitian}

Metode yang digunakan dalam penelitian ini ditunjukkan pada Gambar 4. 


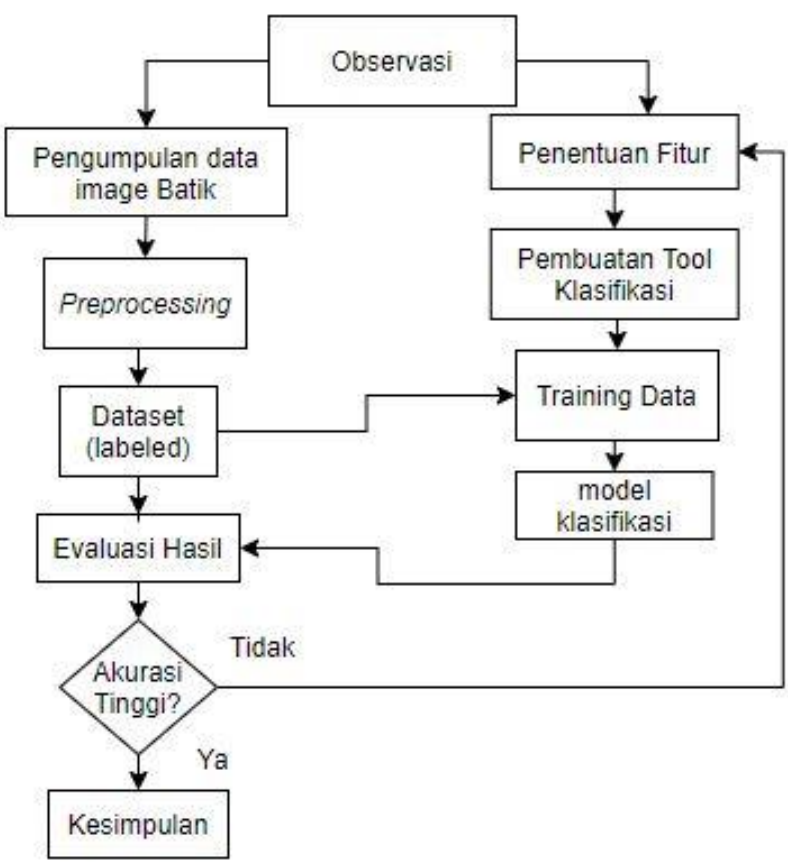

Gambar 4. Metode Penelitian

Pada Gambar 4 ditunjukkan dalam proses metode penelitian yang diawali dengan observasi yaitu datang langsung ke lokasi pengrajin batik di kawasan Surakarta yaitu di rumah batik Laweyan, rumah batik Danar Hadi dan pusat grosir solo (PGS). Observasi dilakukan dengan melihat permasalahan yang terjadi pada batik tradisional Surakarta. Tujuan observasi ke beberapa pengrajin untuk wawancara langsung mengenai permasalahan yang terjadi terhadap batik tradisional Surakarta, macamnya batik tradisional Surakarta, ciri khusus yang membedakan batik tradisional Surakarta dengan batik yang lain.

Dari hasil observasi dilakukan analisis permasalahan. Berdasarkan dari hasil analisis dibuat kesimpulan untuk melakukan identifikasi citra batik tradisional Surakarta berdasarkan dari ciri tekstur. Akuisisi pengetahuan dilakukan dengan melakukan observasi yaitu datang langsung ke lokasi pengrajin batik di kawasan Surakarta yaitu di Laweyan dan home industry batik. Mencari tahu ciri khusus corak batik Surakarta dan makna dari masingmasing corak dari ahlinya. Representasi pengetahuan menggunakan tahapan mengumpulkan data citra berupa image dari citra batik Surakarta. Proses perancangan dan pemrograman dilakukan disesuaikan dengan arsitektur sistem yang dibuat.

Pada penelitian ini data yang digunakan pada pelatihan adalah hasil proses seleksi fitur. Parameter pelatihan yang digunakan adalah laju pembelajaran $(\alpha)$, penurunan laju pembelajaran (Dec $\alpha$ ), minimum laju pembelajaran (Min $\alpha$ ). Maksimum epoch (MaxEpoch) terbaik serta bobot akhir yang digunakan untuk pengujian. Untuk model pelatihan dan pengujian ditunjukkan pada Gambar 5 .

Pada penelitian ini model pengenalan pola untuk identifikasi batik diuji dengan berbagai K-fold cross validation yaitu 2, 3, 5, 6 dan 10. Pada 2-fold cross validation ada 2 kali pengujian yang masing- masing memiliki akurasi. Hasil semua akurasi dihitung nilai ratarata untuk menunjukkan akurasi 2-fold cross validation. Dengan cara yang sama dilakukan untuk pengujian 3-fold cross validation, 5 pengujian untuk 5-fold cross validation, 6 pengujian untuk 6-fold cross validation, 10 pengujian untuk 10-fold cross validation.

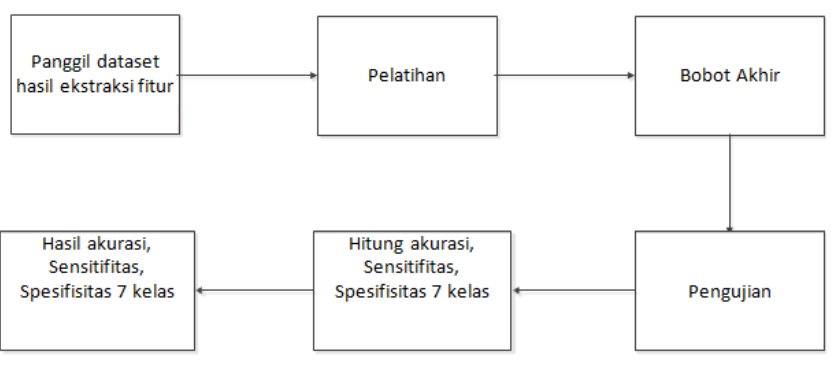

Gambar 5. Model Pelatihan dan Pengujian

Untuk penghitungan akurasi, spesisifisitas, sensitifitas, ditunjukkan pada persamaan (6). Sensitifitas adalah ukuran keberhasilan model mengidentifikasi data positif dengan benar, yang penghitungannya ditunjukkan pada persamaan (7). Spesifisitas adalah ukuran keberhasilan model mengidentifikasi data negatif dengan benar. Perhitungan nilai spesifisitas dapat dihitung dengan persamaan (8).

$$
\begin{aligned}
& \text { akurasi }=\frac{T P+T N}{T P+T N+F P+F N} \% \\
& \text { sensitifitas }=\frac{T P}{T P+F N} \%
\end{aligned}
$$

$$
\text { spesifisitas }=\frac{T N}{T N+F P} \%
$$

\section{Hasil Dan Pembahasan}

Pada penelitian ini model pengenalan pola untuk identifikasi batik tradisional Surakarta diuji dengan berbagai $K$-fold cross validation yaitu 2, 3, 5, 6 dan 10 . Pada 2-fold cross validation ada 2 kali pengujian yang masing-masing memiliki akurasi. Hasil semua akurasi dihitung nilai rata-rata untuk menunjukkan akurasi 2-fold cross validation. Dengan cara yang sama dilakukan untuk pengujian 3-fold cross validation, 5 pengujian untuk 5-fold cross validation, 6 pengujian untuk 6-fold cross validation, 10 pengujian untuk 10-fold cross validation. Data yang digunakan berjumlah 200 data. Pada Tabel 1 menunjukkan hasil uji k-fold.

Tabel 1. Hasil Uji K-Fold

\begin{tabular}{cccc}
\hline \multirow{2}{*}{ Skenario } & \multicolumn{2}{c}{ Jumlah Data } & \multirow{2}{*}{ Akurasi } \\
\cline { 2 - 3 } & Learning & Testing & \\
\hline 1 & 134 & 66 & $80 \%$ \\
2 & 133 & 67 & $76 \%$ \\
3 & 133 & 67 & $74 \%$ \\
\hline
\end{tabular}


Pada pelatihan digunakan untuk memperoleh nilai laju pembelajaran $(\alpha)$ terbaik, penurunan laju pembelajaran (Dec $\alpha$ ), minimum laju pembelajaran (Min $\alpha$ ), dan bobot akhir yang akan digunakan untuk pengujian. Parameterparameter yang digunakan pada pelatihan dengan seleksi fitur dapat dilihat pada Gambar 6. Parameter LVQ proses pelatihan citra batik tradisional Surakarta dengan seleksi fitur ditunjukkan pada Tabel 2.

Data citra yang digunakan berjumlah 200 data. Jumlah fitur pada proses pelatihan untuk identifikasi citra batik tradisional Surakarta adalah 5 fitur. Grafik prosentase ratarata nilai akurasi pada nilai alpha $0.01,0.1,0.5$, data validasi pelatihan dengan seleksi fitur dapat dilihat pada Gambar 7.

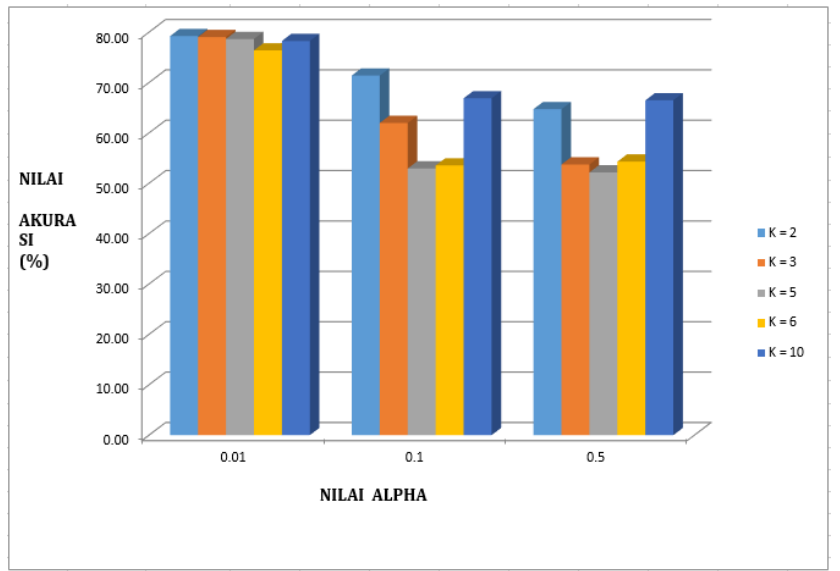

Gambar 6. Grafik Prosentase Rata-Rata Nilai Akurasi Data Validasi Identifikasi Batik Tradisional Surakarta Tanpa Seleksi Fitur

Tabel 2. Parameter LVQ Proses Pelatihan Citra Batik Tradisional

\begin{tabular}{cccccc}
\multicolumn{6}{c}{ Surakarta Dengan Seleksi Fitur } \\
\hline $\begin{array}{c}\text { Jml } \\
\text { fitur }\end{array}$ & $\begin{array}{c}\text { Bobot } \\
\text { Awal }\end{array}$ & K-Fold & $\begin{array}{c}\text { Nilai } \\
(\boldsymbol{\alpha})\end{array}$ & $\begin{array}{c}\text { Nilai } \\
\text { Dec } \\
(\boldsymbol{\alpha})\end{array}$ & $\begin{array}{c}\text { Nilai } \\
\text { Min } \\
(\boldsymbol{\alpha})\end{array}$ \\
\hline 5 & Random & $2,3,5,6,10$ & 0.01 & 0.001 & 0.0001 \\
& & 2.3 .5 .6 .10 & 0.1 & 0.01 & 0.001 \\
& & 2.3 .5 .6 .10 & 0.5 & 0.1 & 0.05
\end{tabular}

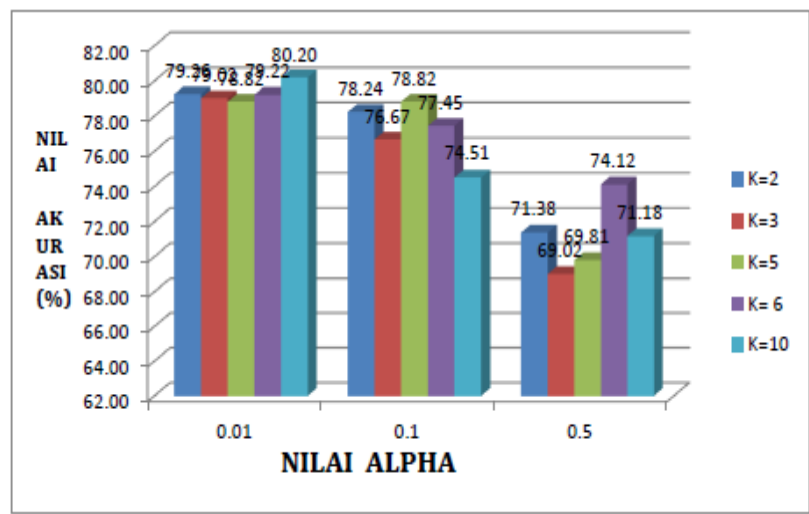

Gambar 7. Grafik prosentase rata-rata nilai akurasi data validasi dengan seleksi fitur
Berdasarkan Gambar 7 dapat dilihat bahwa rata-rata nilai akurasi pelatihan tertinggi sebesar 80,20\% dicapai pada 10-fold dengan nilai $\alpha$ sebesar 0,01. Nilai akurasi, sensitifitas dan spesifisitas dengan seleksi fitur dapat dilihat pada Tabel 3. Selanjutnya dari confusion matrix, dapat diperoleh juga nilai true positive (TP) dan false positive $(F P)$.

Tabel 3 menunjukkan bahwa 10-fold mempunyai nilai akurasi tertinggi sebesar $80.20 \%$ dibandingkan dengan Kfold yang lain. Pada K-fold tersebut dapat diperoleh nilai rata-rata sensitifitas sebesar $70.46 \%$ dan nilai rata-rata spesifisitas sebesar $80.11 \%$. Hasil nilai akurasi, nilai sensitifitas pada 2, 3, 5, 6, 10-fold dapat dilihat bahwa terdapat perbedaan nilai antar kelas yang cukup signifikan.

Pada Tabel 3 dapat dilihat untuk jenis citra batik tradisional Surakarta Sementara sulit untuk identifikasi. Hal ini disebabkan memiliki kesamaan fitur. Sedangkan nilai spesifisitas nilai antar kelas cukup baik dimana perbedaan nilai antar kelas tidak tinggi.

Tabel 3. Nilai Akurasi, Sensitifitas dan Spesifisitas Dengan Seleksi Fitur Citra Batik Tradisional Surakarta

\begin{tabular}{|c|c|c|c|c|c|}
\hline \multirow{2}{*}{$\begin{array}{c}\begin{array}{c}\text { k- } \\
\text { fold }\end{array} \\
2\end{array}$} & \multirow{2}{*}{$\begin{array}{c}\begin{array}{c}\text { Akurasi } \\
(\boldsymbol{\%})\end{array} \\
79.22 \%\end{array}$} & \multicolumn{2}{|c|}{ Sensitifitas (\%) } & \multicolumn{2}{|c|}{ Spesifisitas (\%) } \\
\hline & & Kawung & 0.00 & Kawung & 84.52 \\
\hline & & Parang & 55.00 & Parang & 82.37 \\
\hline & & Satriomanah & 93.33 & Satriomanah & 78.79 \\
\hline & & Sawat & 97.30 & Sawat & 77.80 \\
\hline & & Semenrante & 45.67 & Semenrante & 80.20 \\
\hline & & Sidomukti & 98.88 & Sidomukti & 75.00 \\
\hline & & Truntum & 94.99 & Truntum & 75.20 \\
\hline & & Rata & 69.35 & Rata & 79.13 \\
\hline \multirow[t]{8}{*}{3} & $79.02 \%$ & Kawung & 0.00 & Kawung & 84.52 \\
\hline & & Parang & 55.00 & Parang & 82.16 \\
\hline & & Satriomanah & 93.70 & Satriomanah & 77.00 \\
\hline & & Sawat & 97.30 & Sawat & 77.80 \\
\hline & & Semenrante & 47.00 & Semenrante & 80.20 \\
\hline & & Sidomukti & 97.30 & Sidomukti & 76.00 \\
\hline & & Truntum & 94.20 & Truntum & 75.00 \\
\hline & & Rata & 69.21 & Rata & 78.95 \\
\hline \multirow[t]{8}{*}{5} & $78.82 \%$ & Kawung & 0.00 & Kawung & 84.00 \\
\hline & & Parang & 55.00 & Parang & 82.00 \\
\hline & & Satriomanah & 93.00 & Satriomanah & 78.00 \\
\hline & & Sawat & 97.00 & Sawat & 77.10 \\
\hline & & Semenrante & 46.00 & Semenrante & 80.00 \\
\hline & & Sidomukti & 98.50 & Sidomukti & 75.00 \\
\hline & & Truntum & 94.00 & Truntum & 75.00 \\
\hline & & Rata & 69.07 & Rata & 78.73 \\
\hline \multirow[t]{8}{*}{6} & $79.22 \%$ & Kawung & 0.00 & Kawung & 84.52 \\
\hline & & Parang & 55.00 & Parang & 82.37 \\
\hline & & Satriomanah & 93.33 & Satriomanah & 78.70 \\
\hline & & Sawat & 97.30 & Sawat & 77.80 \\
\hline & & Semenrante & 46.60 & Semenrante & 80.20 \\
\hline & & Sidomukti & 98.80 & Sidomukti & 75.00 \\
\hline & & Truntum & 94.20 & Truntum & 75.20 \\
\hline & & Rata & 69.32 & Rata & 79.11 \\
\hline \multirow[t]{8}{*}{10} & $80.20 \%$ & Kawung & 0.00 & Kawung & 84.52 \\
\hline & & Parang & 60.00 & Parang & 82.25 \\
\hline & & Satriomanah & 93.00 & Satriomanah & 79.00 \\
\hline & & Sawat & 97.00 & Sawat & 78.00 \\
\hline & & Semenrante & 50.10 & Semenrante & 80.00 \\
\hline & & Sidomukti & 98.80 & Sidomukti & 80.00 \\
\hline & & Truntum & 94.29 & Truntum & 77.00 \\
\hline & & Rata & 70.46 & Rata & 80.11 \\
\hline
\end{tabular}




\section{Kesimpulan}

Hasil pengujian menunjukkan bahwa di antara 22 fitur diekstraksi, fitur $\mathrm{idm}^{0}$, energi ${ }^{0}$, energi $90^{\circ}$, korelasi $90^{\circ}$ dan kontras $0^{\circ}$ terpilih menjadi fitur dominan untuk identifikasi citra batik tradisional Surakarta. Akurasi sistem untuk mengidentifikasi citra batik tradisional Surakarta mencapai $74,44 \%$ tanpa seleksi fitur. Sedangkan dengan seleksi fitur menghasilkan akurasi 77,78\%. Hasil ini menunjukkan ada peningkatan sebesar $18,89 \%$, jika dibandingkan dengan hasil akurasi menggunakan 22 fitur yang hanya 58,89\% dengan menggunakan fitur mean value, skewness, kurtosis, standar deviasi dan energi. Sehingga dapat diambil kesimpulan penggunaan ciri tekstur dapat berpengaruh meningkatkan hasil akurasi sebesar $18,89 \%$.

Metode LVQ dan K-Fold cross validation, dapat digunakan untuk melakukan klasifikasi fitur citra batik tradisional Surakarta untuk mengidentifikasi citra batik tradisional Surakarta pada proses pengujian dengan nilai akurasi $77,78 \%$, nilai sensitifitas $66,67 \%$ dan nilai spesifisitas $77,67 \%$. Untuk meningkatkan hasil akurasi yang lebih baik, untuk penelitian selanjutnya akan dilakukan pengujian untuk pemilihan ciri bentuk.

\section{Daftar Pustaka}

[1] A. Kurniawardhani, A. E. Minarno, and F. Bimantoro, "Efficient texture image retrieval of improved completed robust local binary pattern," in 2016 International Conference on Advanced Computer Science and Information Systems, ICACSIS 2016, 2017.

[2] A. Kurniawardhani, N. Suciati, and I. Arieshanti, "Klasifikasi Citra Batik Menggunakan Metode Ekstraksi Ciri Yang Invariant Terhadap Rotasi," JUTI J.

[3] J. Kusanti and R. A. T.S, "Application System for Identification of Surakarta Traditional Batik Images (SABATARA)," SinkrOn, vol. 4, no. 1, p. 5, 2019.

[4] J. Kusanti and A. Suprapto, "Combination of Otsu and Canny Method to Identify the Characteristics of Solo Batik as Surakarta Traditional Batik," in 2019 2nd International Conference of Computer and Informatics Engineering (IC2IE), 2019, pp. 63-68.

[5] A. R. P. dan S. Ambarwati, "Segmentasi Citra Digital Menggunakan Thresholding Otsu untuk Analisa Perbandingan Deteksi Tepi," in Annual Research Seminar 2016, 2016, vol. 2, no. 1, pp. 216-226.

[6] Y. Brasilka and D. Andreswari, "Klasifikasi Citra Batik Besurek Menggunakan Jaringan Syaraf Tiruan Self Organizing Map ( SOM )," J. Rekursif, vol. 3, no. 2, pp. 132-145, 2015.

[7] F. Budiman, A. Suhendra, D. Agushinta, and A. Tarigan, "Determination of SVM-RBF kernel space parameter to optimize accuracy value of Indonesian Batik images classification," J. Comput. Sci., vol. 13, no. 11, 2017.

[8] E. Aribowo, "Segmentasi Citra Batik Berdasarkan Fitur Tekstur Menggunakan Metode Filter Gabor dan Klustering," J. Inform., vol. 10, pp. 1173-1179, 2016.
[9] M. Cheong and K. Loke, "Textile Recognition Using Tchebichef Moments of Co-occurrence Matrices Textile Recognition Using Tchebichef Moments of Co-occurrence Matrices", no. June. 2018.

[10] A. A. Kasim, "Batik Classification with Artificial Neural Network Based on Texture-Shape Feature of Main Ornament," Int. J. Intell. Syst. Appl., no. June, pp. 55-65, 2017.

[11] T. Handhayani, J. Hendryli, and L. Hiryanto, "Comparison of Shallow and Deep Learning Models for Classification of Lasem Batik Patterns," in Proceedings - 2017 1st International Conference on Informatics and Computational Sciences, ICICoS 2017, 2017, no. March 2018.

[12] W. Hapsari and N. A. Haryono, "Segmentasi Warna Pada Batik Menggunakan Pendekatan Hsv Dengan Teknik Linkage," Konf. Nas. Teknol. Inf. dan Komun. (KNASTIK 2016), no. November, pp. 268-275, 2016.

[13] I. G. S. Rahayuda, "Texture Analysis on Image Motif of Endek Bali using K-Nearest Neighbor Classification Method," Int. J. Adv. Comput. Sci. Appl., vol. 6, no. 9, pp. 205-211, 2015.

[14] V. Pebrianasari, E. Mulyanto, and D. Erlin, "Analisis pengenalan motif batik Pekalongan Menggunakan Algoritma Backpropagation," Techno.COM, vol. 14, no. 4, pp. 281-290, 2015.

[15] K. Meccasia, B. Hidayat, and U. Sunarya, "Klasifikasi Motif Batik Banyuwangi Menggunakan Metode Ekstraksi Ciri Wavelet Dan Metode Klasifikasi Fuzzy Logic," in $e$ Proceeding of Engineering (2015), 2015, vol. 2, no. 2, pp. 2760-2766.

[16] A. A. Kasim, "Fuzzy C Means for Image Batik Clustering based on Spatial Features," Int. J. Comput. Appl., vol. 117, no. 2, pp. 2-5, 2015.

[17] A. E. Minarno, Y. Munarko, F. Bimantoro, A. Kurniawardhani, and N. Suciati, "Batik Image Retrieval Based on Enhanced Micro-Structure Descriptor," in 2014 Asia-Pacific Conference on Computer Aided System Engineering, APCASE 2014, 2016, no. June.

[18] I. D. E. K. R et al., "Klasifikasi Batik Menggunakan KNN Berbasis Wavelet," in Seminar Nasional Teknologi Informasi dan Komunikasi 2016 (SENTIKA 2016), 2016, vol. 2016, no. Sentika, pp. 18-19.

[19] S. Batik, "Batik fabric Atlanta with spesial cotton and original handmade," pp. 2-5, 2015.

[20] S. dan D. H. Doellah, DHO_4-6_FA7_lores_single.pdf. 2012.

[21] A. Syahrin, The batik motif, no. June 2015, 2015.

[22] L. Fausett, Fundamentals Of Neural Network Architectures, Algorithms, and Applications, vol. 116, no. 0. 1994.

[23] W. Gibson, Pattern Recognition, vol. 53, no. 9. 2013.

[24] B. R. Gonzalez, R. C., Woods, R. E., \& Masters, "Digital Image Processing Using Matlab - Gonzalez Woods \& Eddins." 2013.

[25] H. Refaeilzadeh, P., Tang, L. dan Liu, Cross Validation, Encyclopedia of Biometric. 